\title{
Penis Erectile Tissue
}

National Cancer Institute

\section{Source}

National Cancer Institute. Penis Erectile Tissue. NCI Thesaurus. Code C49269.

The erectile tissues of the penis. It includes the dorsal corpora cavernosa and the ventral corpus spongiosum. Their structure consists of multiple vascular spaces that are surrounded by smooth muscle. 